\title{
"Wygrani” i „przegrani”. Analiza zmian poparcia uzyskanego przez radnych sejmików wojewódzkich kandydujących do parlamentu
}

Abstrakt: Problematyka kreacji instytucjonalnych elit władzy jest zagadnieniem, które absorbowało i nadal absorbuje przedstawicieli nauk społecznych. Procesy rekrutacji i selekcji, zdobywania poparcia społecznego i oddolnej legitymacji zdają się interesować nie tylko świat ludzi nauki, praktyków sfery politycznej, lecz także obywateli - wyborców. W niniejszym artykule podjęto próbę udzielenia odpowiedzi na pytania dotyczące udziału radnych sejmików województw wybranych w $2014 \mathrm{r}$. w wyborach parlamentarnych kolejnego roku. Zastanawiano się nad kwestią samej skali aktywności radnych, problemami ich związania lub nie z poszczególnym blokiem politycznym i z określonym terytorium, wreszcie analizie poddano zmiany dotyczące uzyskanego przez nich poparcia wyborczego.

Słowa kluczowe: radni sejmików wojewódzkich, wybory parlamentarne, kariera polityczna, „wygrani”, „przegrani”

"Winners" and "Iosers." Analysis of changes in the support received by provincial assembly councillors running for parliament

Abstract: The issues of the creation of institutional elites of the authorities constitute a problem that absorbs representatives of social sciences to this day. The processes of recruitment and selection, gaining social support and bottom-up legitimization seem to absorb not only the world of academics and practitioners of the political sphere but also citizens-electors. In this paper, an attempt has been made to give answers to questions concerning the participation of provincial assembly councillors elected in 2014 in the parliamentary elections held the following year. The issue of the scale of councillors' activity, problems of their connection or its lack with a specific political bloc and specific territory have been considered, while the rest of the analysis refers to changes regarding the electoral support they gained.

Keywords: provincial assembly councillors, parliamentary elections, political career, "winners", "losers" 


\section{Wprowadzenie}

Wybory parlamentarne 2015 r. doprowadziły do alternacji władzy i zmian w obrębie polskiej sceny politycznej. Przyniosły bezwarunkowe zwycięstwo jednemu blokowi politycznemu, niwelując przy tym konieczność tworzenia koalicji gabinetowej. W obrębie Izby Niższej umieściły dwa ugrupowania, które wyłoniły się kilka miesięcy czy nawet tygodni przed oficjalnym początkiem kampanii wyborczej. Zmiotły także z instytucjonalnej sceny politycznej lewicę, obecną we wszystkich dotychczasowych parlamentach. Pewną zapowiedzią zachodzących zmian był w dużej mierze zaskakujący wynik wyborów prezydenckich, odbywających się kilka miesięcy wcześniej. Ubiegającego się o reelekcję i będącego liderem w sondażach opinii publicznej Bronisława Komorowskiego zastąpił kandydat zgłoszony przez prawą stronę sceny politycznej Andrzej Duda.

Rok wcześnej odbyły się w Polsce wybory samorządowe, w których wybierano władztwo lokalne gmin i powiatów, a także kreowano samorząd regionu. Rok później, czyli jesienią 2015 r., część wybranych wówczas samorządowców aspirowała do parlamentu. Dla niektórych zakończyło się to sukcesem, dla innych porażką. Natomiast $\mathrm{z}$ perspektywy podjętych $\mathrm{w}$ niniejszym artykule kwestii interesującym zagadnieniem stało się, czy i w jakim stopniu radni samorządów wojewódzkich rozbudowali swoje poparcie wśród wyborców. Regionalne sceny polityczne mają swoją specyfikę. W przeciwieństwie do władztwa lokalnego trudno tu przyjąć założenie o bezpośredniej znajomości kandydatów przez wyborców, dlatego rolę nie tylko selekcjonera kadr, lecz także drogowskazu co do ich kompetencji i umiejętności pełnią partie polityczne, co finalnie prowadzi do sytuacji, w której samorząd wojewódzki jest najbardziej upartyjnionym poziomem samorządu w Polce.

\section{Problematyka artykułu}

W literaturze przedmiotu wskazuje się na znaczenie samorządu terytorialnego dla współczesnego państwa, społeczeństwa i demokracji jako formy ustrojowej. Instytucje samorządowe są zatem „kluczowym narzędziem codziennej realizacji ustroju demokratycznego" ${ }^{1}$, a samorząd stanowi "niezwykle ważny segment demokratycznego państwa"2. Jacek Pokładecki pisze, że

Nowożytny samorząd niezależnie od sposobu jego definiowania jest immanentnym elementem demokratycznego państwa. Instytucje samorządowe, ze swojego

${ }^{1}$ J.T. Hryniewicz, Analiza funkcjonowania samorzadu lokalnego w oparciu o kluczowe kategorie nauk o zarządzaniu: misje, cele, własność, kontekst organizacyjny i efektywność, [w:] 20 lat samorzadu terytorialnego w Polsce. Sukcesy, porażki, perspektywy, red. K. Mieczkowska-Czerniak, K. Radzik-Maruszak, Lublin 2012, s. 79.

2 S. Sulowski, Wprowadzenie, [w:] Polityka na szczeblu samorzadu terytorialnego, red. S. Sulowski, „Studia Politologiczne” 20, Warszawa 2011, s. 17. 
ustrojowego założenia, mają pozostawać jak najbliżej społeczności lokalnej (regionalnej) i realizować jej interesy ${ }^{3}$.

Kwestia władztwa samorządowego może być ujmowana $\mathrm{z}$ różnych perspektyw. Na pierwszym planie mogą się sytuować zagadnienia związane z regulacjami normatywnymi dotyczącymi władzy w gminie, powiecie czy regionie. Sednem rozważań może być także funkcjonalność przyjętych rozwiązań ustrojowych czy też próba odpowiedzi na pytania dotyczące realnego działania samorządu w kontekście relacji obywatele-włodarze-instytucje. Można zastanawiać się nad specyfiką procesów politycznych zachodzących na szczeblu lokalnym i regionalnym, mechanizmami kreacji władztwa poszczególnych poziomów, wcześniej zaś nad determinantami zwycięstwa lub przegranej w wyborach samorządowych. Można wreszcie, jak ma to miejsce w niniejszym artykule, podnosić kwestię zainteresowania rozwojem kariery politycznej samorządowców na szczeblu centralnym, stosunku do tego samych bloków politycznych oraz realnych efektów umieszczania na parlamentarnych listach wyborczych radnych sejmików.

Problematyka niniejszego artykułu koncentruje się wokół dwóch głównych zagadnień. Pierwszym $\mathrm{z}$ nich jest próba udzielania odpowiedzi na pytanie o to, czy radni sejmików byli zainteresowani kandydowaniem do parlamentu? Istnieją liczne podobieństwa między wyborami do samorządu regionalnego i Sejmu RP (próg wyborczy preferujący bloki dysponujące określonym poparciem w regionie/w kraju, liczba głosów potrzebnych do uzyskania mandatu, znaczenie popularności bloku wyborczego i dodatkowo przy nikłej znajomości bezpośredniej kandydatów rola miejsca wyborczego na liście), które pozwalają postawić tezę, że dla części radnych kariera samorządowa stanowiła punkt wyjścia do kariery politycznej. Wprawdzie biorąc pod uwagę kompetencje władzy regionalnej, trudno doszukiwać się zagadnień mających bezpośrednie (a szczególnie krótkoterminowe) przełożenie na jakość życia ludności ${ }^{4}$ i ich „wdzięczność” wyrażoną w głosowaniu, jednak prestiż i możliwości, jakie daje mandat (czy stanowisko w zarządzie województwa), mogą być wykorzystane do budowania poparcia wyborczego. Czy zatem ów rok, który upłynął od wyborów samorządowych, został przez radnych właściwie wykorzystany odnośnie do budowania poparcia i finalnego wzrostu liczby głosów? Odpowiedź na drugi problem badawczy zredukowano do porównania wyników uzyskanych w wyborach 2014 i 2015 r., zdając sobie sprawę z wielu czynników, które również odgrywały rolę (obecność na listach ugrupowań do Sejmu RP polityków popularnych w skali kraju oraz osób mających przyciągnąć uwagę wyborców), niemniej nie mogły one ulec zhomogenizowanej parametryzacji.

3 J. Pokładecki, Aktywność w wyborach do organów samorządu terytorialnego jako przejaw partycypacji politycznej, [w:] Partycypacja społeczna w samorządzie terytorialnym, red. B. Dolnicki, Warszawa 2014, s. 226.

${ }^{4}$ B. Gąciaż, J. Bartkowski, Samorzad a rozwój. Instytucje, obywatele, podmiotowość, Warszawa 2012, s. 190. 
Możliwe stało się jednak określenie miejsc na listach wyborczych, na których sytuowano samorządowców, i wskazanie poziomu ich atrakcyjności dla komitetów.

Adekwatne do udzielenia odpowiedzi na te pytania okazało się skorzystanie z badań niereaktywnych i zastosowanie metody badawczej opartej na analizie dokumentów urzędowych. Biorąc pod uwagę upartyjnienie regionalnych scen politycznych, analizy danych dokonano w podziale na poszczególne partie polityczne. Jak wskazano, ograniczono się do wyborów samorządowych 2014 i wyborów parlamentarnych 2015 r. Podstawę orzekania stanowią dane Państwowej Komisji Wyborczej pozwalające porównać poparcie wyborcze, którym dysponowali kandydaci poszczególnych bloków politycznych, najpierw uzyskując mandaty radnych samorządów wojewódzkich, a następnie walcząc o miejsca w parlamencie.

W tytule zasygnalizowano koncentrację podjętych rozważań na ujęciu bipolarnym, gdzie mamy do czynienia $\mathrm{z}$ „wygranymi” i „przegranymi”. Wbrew pozorom „wygranymi” nie są jednak radni sejmiku, którzy uzyskali mandat parlamentarzysty. Są nimi osoby, które w wyborach parlamentarnych uzyskały lepszy wynik niż we wcześniejszych wyborach samorządowych. Być może czytelnikowi takie rozwiązanie wyda się kontrowersyjne, wszak zwycięzcą jest ten, kto dążąc do celu, pokonuje innych konkurentów i ów cel osiąga. Jednak z perspektywy niewyborczej, lecz społecznej istotne jest utrzymanie, a jeszcze lepiej poszerzenie akceptacji, zaufania i głosów wyborców, pozostanie/stanie się „ich” kandydatem nawet wtedy, gdy na listach wyborczych obecne są osoby o wysokiej identyfikowalności: liderzy partii, parlamentarzyści, ludzie kultury, nauki, sztuki czy artyści. „Wygranymi” stają się także partie polityczne, które w efektywny sposób wykorzystały potencjał osób usytuowanych w kręgach ich interesariuszy, zapraszając na listy wyborcze kandydatów, których potencjał i dokonania docenili wyborcy. Analogicznie „przegranym" staje się ten radny, który w ciągu roku stracił część swojego poparcia lub na poziomie instytucjonalnym komitet wyborczy, konstruujący listę wyborczą do parlamentu.

Oczywiście taka analiza ilościowa pomija wiele aspektów. Przy wyraźnym upartyjnieniu regionalnych scen politycznych ważne stają się notowania poszczególnych partii politycznych - one też będą wpływać na szanse radnych kandydujących w wyborach parlamentarnych. Odstęp czasowy między obiema elekcjami również jest istotny. Z perspektywy działania na rzecz mieszkańców rok to bardzo mało, szczególnie wtedy gdy ktoś chce zamienić mandat samorządowca na mandat parlamentarzysty, acz z perspektywy quasi-replikacji działań z zakresu marketingu politycznego taka perspektywa czasowa wydaje się bardzo atrakcyjna. Inaczej jest w przypadku konkurencji na listach wyborczych w wyborach parlamentarnych - tu w szranki z regionalnymi aktywistami i działaczami często stają politycy „z pierwszych stron gazet”, ci, którzy znani są szerszej opinii publicznej. Wreszcie decyzje komitetów wyborczych, aby sięgnąć po radnych sejmików w wyborach parlamentarnych, mogą przebiegać w rozmaitych warunkach, co przy takim schemacie nie jest analizowane. Konkludując, zastosowane 
tu wyjaśnianie nomotetyczne ma swoje wady, polegające na redukcji rozmaitych czynników endogennych i egzogennych, jednak pozwala porównać radnych kandydatów różnych bloków, a to stanowi clue podjętych w artykule rozważań.

\section{Wybory do sejmików województw w 2014 r.}

Dnia 16 listopada 2014 r. odbyły się w Polsce wybory samorządowe, które wyłoniły składy rad powiatów i sejmików województw piątej kadencji. Przeprowadzono je do 2825 rad, z czego zdecydowaną większość stanowiły rady gmin (2477). Wybierano także składy 18 rad dzielnic miasta stołecznego Warszawy, 314 rad powiatów oraz 16 sejmików wojewódzkich. Wybierano łącznie 46790 radnych (radni rad gmin - 39539 osób, radni rad dzielnic Warszawy - 423, radni powiatów 6276). O 555 mandatów w sejmikach regionalnych ubiegało się 8901 osób, co oznacza, że o jeden mandat walczyło tu średnio 16 kandydatów ${ }^{5}$. Frekwencja wyborcza w 2014 r. wyniosła 47,21\%, a uwagę zwracała bardzo wysoka liczba głosów nieważnych. Było ich $2525210^{6}$.

Już wcześniej podkreślano zasadniczą rolę samorządu terytorialnego dla społeczeństw, współczesnych państw oraz demokracji, niemniej nie oznacza to braku krytyki istniejących rozwiązań i ich realizacji praktycznej. Wprawdzie działania samorządu terytorialnego są w Polsce lepiej oceniane niż efekty aktywności władz szczebla centralnego, niemniej nie oznacza to braku jego krytyki różnych aspektów jego funkcjonowania. Podkreśla się choćby, że „reforma samorządowa miała przybliżyć władzę do obywatela, nie przyczyniła się w znaczącym stopniu do wzrostu zaufania do niej wśród obywateli" miejscach wzmocniła ona możliwości wpływu lokalnych grup interesów ${ }^{8}$. W literaturze przedmiotu wskazuje się, że zjawisko upartyjnienia samorządów ma charakter narastający, pojawiają się też nowe formy i rozwiązania w tym zakresie. Dążące do maksymalizacji stanu posiadania w samorządach ugrupowania wypracowały zróżnicowane strategie wyborcze, gdzie konkurencyjnym dla wystawiania własnych list wyborczych rozwiązaniem jest inspirowanie i patronat nad lokalnymi komitetami wyborczymi, korzystającymi z „szyldów” organizacji społecznych.

${ }^{5}$ Obwieszczenie Państwowej Komisji Wyborczej z dnia 23 listopada 2014 r. o zbiorczych wynikach wyborów do rad na obszarze kraju, przeprowadzonych w dniu 16 listopada 2014 r. (Dz.U. z 2014 r. poz. 1640), http://pkw.gov.pl/obwieszczenia-i-komunikaty-samorzad-2014/obwieszczenie-panstwowej-komisji-wyborczej-z-dnia-23-listopada-2014-r-o-zbiorczych-wynikach-wyborow-do-rad-na-obszarze-kraju-przeprowadzonych-w-dniu-16-listopada-2014-r.html (dostęp: 28 listopada 2015).

${ }^{6}$ http://samorzad2014.pkw.gov.pl/357_rady_woj (dostęp: 28 listopada 2015).

7 K. Dojwa, Samorzad terytorialny $i$ władze samorzadowe w percepcji społecznej. Wybrane aspekty socjologiczne, [w:] Polityka na szczeblu samorzadu..., s. 21-40.

${ }^{8}$ J. Jaskiernia, Konstytucyjny model samorządu terytorialnego - czy przetrwał próbę czasu?, [w:] XX lat samorzadu terytorialnego w Polsce. Doświadczenia-problemy-perspektywy, red. J. Kowalik, A. Bednarz, Toruń 2011, s. 38. 
Z punktu widzenia partii możliwość wyboru jednej lub drugiej strategii wyborczej ma wymiar pozytywny, inaczej jest jednak wtedy, gdy weźmiemy pod uwagę społeczeństwo obywatelskie i zaufanie obywateli do rządzących. Proces upartyjnienia przyczynia się do umacniania i utrwalania w samorządach wpływów krajowych partii politycznych, a co istotniejsze - do ograniczenia przestrzeni dla autentycznych, społecznych komitetów wyborczych, które są zmuszane do uczestnictwa w nierównej rywalizacji z reprezentacjami silnych partii politycznych ${ }^{9}$.

"Maskowanie" partii politycznych w samorządach ma miejsce przede wszystkim na poziomie lokalnym, w sytuacji stosunkowo rozległych okręgów wyborczych w wyborach do samorządu regionalnego i obowiązującego 5-procentowego progu wyborczego jego zasięg jest ograniczony. Dlatego też radni regionów w porównaniu $\mathrm{z}$ radnymi gmin i powiatów - są warstwą stosunkowo silnie upartyjnioną ${ }^{10}$, co oznacza, że ich zdecydowana większość uzyskała mandat, kandydując z list komitetów związanych z podmiotami sceny ogólnopolskiej, wcześniej zaś to właśnie tego rodzaju podmioty nadawały główny ton działaniom selekcyjnym.

Sytuacja odgrywania ról demiurgów regionalnej polityki przez partie polityczne i bloki o charakterze ogólnopolskim miała miejsce także w 2014 r. Kandydaci partii politycznych dominowali wśród wszystkich kandydatów do sejmików województw, stanowiąc ponad $64 \%$ ogółu ${ }^{11}$, jeszcze bardziej widoczne stało się to po ogłoszeniu wyników wyborów. W przypadku $10 \mathrm{z} 16$ województw w składach sejmików nie znaleźli się kandydaci reprezentujący inne podmioty niż te obecne na ogólnopolskiej scenie politycznej. Wśród wszystkich radnych znalazło się finalnie zaledwie 20 osób niereprezentujących głównych bloków politycznych obecnych w parlamencie, niemniej w wielu przypadkach radni reprezentowali podmioty i środowiska, które z polityką centralną były (w jednym przypadku stały się) związane.

Tabela 1. Liczba mandatów uzyskanych przez poszczególne partie w radach sejmików w 2014 r.

\begin{tabular}{|l|c|c|c|c|c|c|}
\hline \multicolumn{1}{|c|}{ Województwo } & $\begin{array}{c}\text { Liczba } \\
\text { mandatów }\end{array}$ & $\begin{array}{c}\text { KW } \\
\text { PO RP }\end{array}$ & $\begin{array}{c}\text { KW } \\
\text { PiS }\end{array}$ & $\begin{array}{c}\text { KW } \\
\text { PSL }\end{array}$ & $\begin{array}{c}\text { KKW } \\
\text { SLD-LR }\end{array}$ & Inne \\
\hline dolnośląskie & 36 & 16 & 9 & 5 & 2 & 4 \\
\hline kujawsko-pomorskie & 33 & 14 & 7 & 10 & 2 & 0 \\
\hline lubelskie & 33 & 7 & 13 & 12 & 1 & 0 \\
\hline
\end{tabular}

9 J. Bober et al., Narastajace dysfunkcje, zasadnicze dylematy, konieczne działania. Raport o stanie samorządności terytorialnej w Polsce, Kraków 2013, s. 32.

10 Ibidem, s. 41; oraz A. Antoszewski, Wszystko przez ten system... (wyborczy), [w:] Gra o regiony. Wybory do sejmików województw w 2010 roku, red. R. Alberski, M. Cichosz, K. Kobielska, Wrocław 2013, s. 336

11 G. Kocot, Wybory samorządowe 2014 w Polsce. Przepisy wyborcze, frekwencja i wyniki, „Zeszyty Naukowe Towarzystwa Doktorantów UJ. Nauki społeczne” 2015, nr 11, s. 25-47. 


\begin{tabular}{|l|r|r|r|r|r|l|}
\hline lubuskie & 30 & 10 & 5 & 8 & 5 & 2 \\
\hline lódzkie & 33 & 10 & 12 & 10 & 1 & 0 \\
\hline małopolskie & 39 & 14 & 17 & 8 & 0 & 0 \\
\hline mazowieckie & 51 & 15 & 19 & 16 & 1 & 0 \\
\hline opolskie & 30 & 9 & 5 & 8 & 1 & 7 \\
\hline podkarpackie & 33 & 5 & 19 & 9 & 0 & 0 \\
\hline podlaskie & 30 & 8 & 12 & 9 & 1 & 0 \\
\hline pomorskie & 33 & 17 & 9 & 7 & 0 & 0 \\
\hline śląskie & 45 & 17 & 16 & 5 & 3 & 4 \\
\hline świętokrzyskie & 30 & 3 & 8 & 17 & 2 & 0 \\
\hline warmińsko-mazurskie & 30 & 9 & 6 & 14 & 1 & 0 \\
\hline wielkopolskie & 39 & 13 & 8 & 12 & 4 & 2 \\
\hline zachodniopomorskie & 30 & 12 & 6 & 7 & 4 & 1 \\
\hline
\end{tabular}

Źródło: opracowanie własne na podstawie Podział mandatów w sejmikach województw według komitetów wyborczych, http://pkw.gov.pl/g2/oryginal/2014_11/8b4fcc8febb13dc7d88f8e386e3ab5a4.pdf.

Kwestia bloków wyborczych, które nie stanowiły replikacji ugrupowań obecnych na ogólnopolskiej scenie politycznej, w dalszej części artykułu nie będzie już podnoszona, dlatego w tym miejscu należy zwrócić uwagę na kilka zagadnień. W gronie radnych niekandydujących z list głównych podmiotów ogólnopolskiej sceny politycznej najwięcej mandatów uzyskał KKW Mniejszość Niemiecka ${ }^{12}$, umieszczając w sejmiku Opolszczyzny siedmiu radnych. Mniejszość nie należy wprawdzie do głównych aktorów polskiej polityki, niemniej w Sejmie RP dysponuje stałą reprezentacją, dodatkowo trudno odmówić jej wysokiego poziomu instytucjonalizacji. Gdyby nie asymetria prawna, być może w taki sam sposób moglibyśmy postrzegać funkcjonujący na Śląsku KW Ruch Autonomii Śląska, uzyskujący w sejmiku województwa cztery mandaty. Taką samą reprezentację na Dolnym Śląsku zanotował w 2014 r. KKW Bezpartyjni Samorządowcy, stanowiący następnie podstawę do startu w wyborach

12 Oczywiście umieszczenie Mniejszości Niemieckiej poza główną sceną polityczną szczebla centralnego ma tu charakter raczej symboliczny. Podmiot dysponuje stałą reprezentacją w Izbie Niższej, ale poparcie dla niego ma charakter regionalny, dodatkowo uzyskanie reprezentacji w Izbie Niższej ułatwia czy wręcz zapewnia dyskryminacja pozytywna mniejszości niemieckiej w Polsce. W 2015 r. lista zgłoszona przez Komitet Wyborczy Wyborców Mniejszość Niemiecka w okręgu wyborczym nr 21 uzyskała jeden mandat. Por. Obwieszczenie Państwowej Komisji Wyborczej z dnia 27 października 2015 r. o wynikach wyborów do Sejmu Rzeczypospolitej Polskiej przeprowadzonych w dniu 25 października 2015 r. (Dz.U. z 2015 r. poz. 1731). 
prezydenckich jego lidera Pawła Kukiza ${ }^{13}$, będący wreszcie punktem wyjścia do obecności podmiotu na parlamentarnej scenie politycznej w 2015 r. Dwa następne podmioty: KWW Lepsze Lubuskie - Bezpartyjny Samorząd, Województwo Lubuskie oraz KWW Ryszarda Grobelnego Teraz Wielkopolska uzyskały po dwa mandaty, kolejny zaś: Bezpartyjni KWW Pomorze Zachodnie, Województwo Zachodniopomorskie zaznaczył swoją obecność w samorządzie regionu, zdobywając jeden mandat ${ }^{14}$.

Jak już wskazano, zdecydowana większość mandatów w sejmikach wojewódzkich przypadła w udziale ugrupowaniom partyjnym ogólnopolskiej sceny politycznej. Zwycięzcą wyborów na szczeblu regionów w 2014 r. była Platforma Obywatelska RP, zdobywająca 179 mandatów. Porównywalny był także wynik Prawa i Sprawiedliwości, wynoszący 171 mandatów. Trzeci wynik należał do Ludowców - wedle danych PKW Polskie Stronnictwo Ludowe umieściło w samorządach regionów 157 radnych. Czwartą pozycję (28 mandatów) zajęła lewica skupiona wokół Sojuszu Lewicy Demokratycznej (występująca w wyborach samorządowych jako KKW SLD - Lewica Razem). Zatem poza wpływem głównych ugrupowań ogólnopolskiej sceny politycznej 2014 r. znalazło się jedynie 3,6\% radnych sejmików.

\section{Wybory parlamentarne 2015 r.}

Dnia 25 października 2015 r. odbyły się w Polsce wybory parlamentarne wyłoniono 460-osobową Izbę Niższą VIII kadencji oraz liczącą 100 reprezentantów Izbę Wyższą IX kadencji. W wyborach do Sejmu RP kandydowało 7858 osób, natomiast do Senatu 423 osoby. Frekwencja wyniosła 50,92\%, liczba głosów nieważnych wynosiła $394664^{15} \mathrm{i}$ była zauważalnie niższa niż w wyborach samorządowych $2014 \mathrm{r}$.

Zwycięzcą wyborów parlamentarnych okazał się Komitet Wyborczy Prawo i Sprawiedliwość, który uzyskał możliwość samodzielnego rządzenia. Drugą pozycję zajął Komitet Wyborczy Platforma Obywatelska RP, trzecią - Komitet Wyborczy Wyborców „Kukiz’15”. Poza tym w Sejmie RP znalazły się jeszcze dwa podmioty: Komitet Wyborczy Nowoczesna Ryszarda Petru oraz Komitet Wyborczy Polskie Stronnictwo Ludowe $^{16}$. Sejm RP VIII kadencji stał się izbą, w której zabrakło postkomunistycznej lewicy. Sojusz Lewicy Demokratycznej, tworzący listy wyborcze wraz z innymi podmiotami jako Koalicyjny Komitet Wyborczy Zjednoczona Lewica SLD + TR + PPS + UP + Zieloni, nie przekroczył właściwego dla koalicji progu wyborczego.

13 Paweł Kukiz uzyskał w wyborach prezydenckich w 2015 r. 3099079 głosów, czyli poparcie $20,80 \%$ osób glosujących, zajmując trzecią pozycję w wyścigu wyborczym. Por. http://prezydent 2015 . pkw.gov.pl/319_Pierwsze_glosowanie (dostęp: 11 listopada 2015).

14 Podział mandatów w sejmikach województw według komitetów wyborczych, http://pkw.gov. pl/g2/oryginal/2014_11/8b4fcc8febb13dc7d88f8e386e3ab5a4.pdf (dostęp: 11 listopada 2015).

15 http://parlament2015.pkw.gov.pl/349_Wyniki_Sejm (dostęp: 10 listopada 2015).

16 Ibidem. 
Wykres 1. Liczba kandydatów, poparcie wyborcze oraz liczba uzyskanych mandatów przez poszczególne komitety wyborcze w wyborach do Sejmu RP 2015 r.

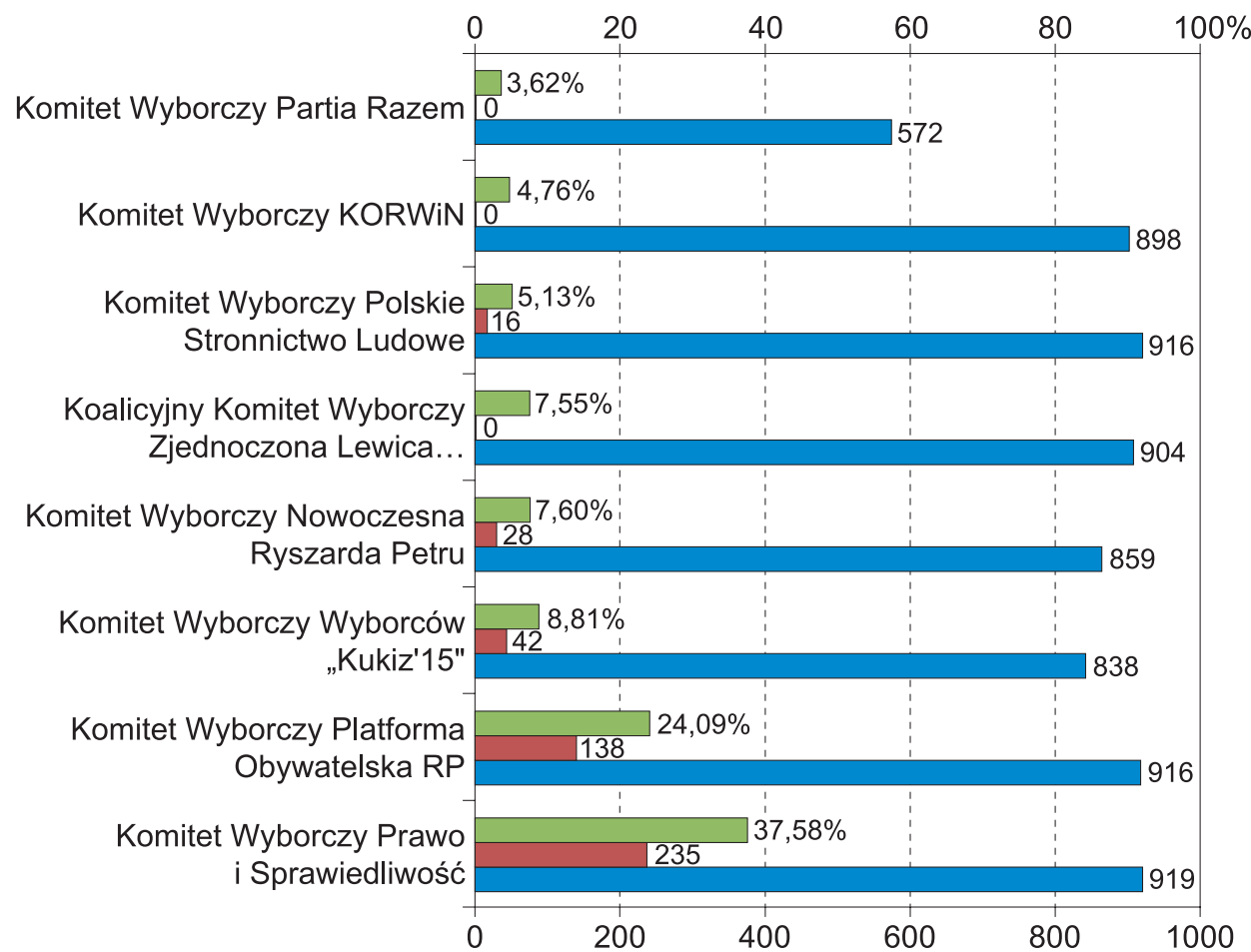

$\square$ procent oddanych głosów

$\square$ liczba uzyskanych mandatów

$\square$ liczba kandydatów zgłoszonych przez komitet do Sejmu RP

*uwzględniono jedynie komitety uzyskujące poparcie przekraczające 3\% głosów.

Źródło: opracowanie własne na podstawie Wyniki wyborów do Sejmu RP oraz Wykaz komitetów wyborczych, www.pkw.go.pl.

Komitet utworzony przez Prawo i Sprawiedliwość zwyciężył nie tylko w Izbie Niższej, utrzymał swoją przewagę nad innymi partiami i blokami także w Izbie Wyższej. Partia kierowana przez Jarosława Kaczyńskiego uzyskała tu 61 mandatów. Drugą pozycję zajął Komitet Wyborczy Platforma Obywatelska RP, uzyskując 34 mandaty. Znaczenie partii politycznych widoczne było zatem również w przypadku wyborów do Izby Wyższej, gdzie zwycięstwo wyborcze nie jest zapośredniczone przez wynik komitetu w skali kraju. Normatywnie partyjną nominacją dysponował jeszcze jeden reprezentant w Izbie Wyższej (reprezentujący Komitet Wyborczy Polskie Stronnictwo Ludowe), kolejne cztery osoby 
rekrutowały się z komitetów wyborczych wyborców, niemniej z perspektywy dotychczasowych realizacji trudno jest nazwać ich outsiderami politycznymi ${ }^{17}$.

\section{Radni sejmików w wyścigu do parlamentu}

Do obu izb polskiego parlamentu kandydowało w 2015 r. 242 radnych sejmików województw ${ }^{18}, 211$ radnych kandydowało do Sejmu RP, kolejnych 31 do Senatu RP. Stanowiło to niemal 44\% wszystkich radnych regionów. Biorąc pod uwagę stosunkowo krótki czas, który minął od wyborów samorządowych, ów odsetek wydaje się stosunkowo wysoki, gdyż trudno tu mówić o realizacji planów i postulatów, które deklarowali kandydaci na radnych, uzyskując mandat radnego z rąk mieszkańców.

Aspiracje rozwoju kariery politycznej na szczeblu państwowym oraz relatywna na to zgoda poszczególnych bloków politycznych były zróżnicowane. Wśród radnych kandydatów do Sejmu RP najwięcej było aktywistów PSL (85 osób, czyli ponad połowa radnych regionów tego ugrupowania), następnie komitetu Prawa i Sprawiedliwości (63, ponad jedna trzecia radnych) oraz Platformy Obywatelskiej RP (48 osób, ponad jedna czwarta $z$ radnych ugrupowania). W przypadku lewicy (Koalicyjny Komitet Wyborczy Zjednoczona Lewica SLD + TR + PPS + UP + Zieloni) ta liczba była niższa - wyniosła 11 osób. Jeśli chodzi o inne podmioty ówczesnej sceny politycznej, to wśród radnych kandydatów znalazł się także lider ruchu Kukiz'15 (tworzący w 2014 r. blok bezpartyjnych samorządowców). Dodatkowo cztery osoby kandydowały z list komitetów wyborczych wyborców. W przypadku Senatu RP najwięcej radnych kandydatów było ponownie na listach PSL (12 osób), następnie PiS (11 kandydatów) oraz PO (pięć osób). Trzy osoby kandydowały z list komitetów wyborców.

Biorąc pod uwagę liczbę wszystkich kandydatów obecnych na listach głównych ugrupowań rejestrujących listy do Sejmu RP (PiS, PO, PSL, Kukiz 15’ oraz SLD), odsetek radnych był stosunkowo niski ${ }^{19}$ i wynosił $4,6 \%$.

Z grona kandydujących radnych mandaty uzyskało 55 osób, czyli 22,7\% kandydatów. Z perspektywy samorządowców ujmowanych in gremio moglibyśmy uznać

17 Kandydaci niezależni do Senatu RP, którzy uzyskali mandat, to: Lidia Staroń (Komitet Wyborczy Wyborców Lidia Staroń - Zawsze po stronie ludzi), Marek Borowski (Komitet Wyborczy Wyborców Marka Borowskiego), Grzegorz Bielecki (Komitet Wyborczy Wyborców Grzegorza Bieleckiego), Jarosław Obremski (Komitet Wyborczy Wyborców Obremski - niezależny Senator z Wrocławia), http://parlament2015.pkw.gov.pl/351_Wyniki_Senat (dostęp: 10 listopada 2015).

18 Ponieważ tuż po wyborach samorządowych, a także później rezygnowano z mandatu radnego, do dalszych analiz statystycznych wykorzystano wykazy radnych sejmików województw opublikowane na właściwych portalach internetowych samorządów wojewódzkich (BIP), przyjmując skład rad na dzień 25 października 2015.

19 Więcej na ten temat K. Dojwa-Turczyńska, Z samorządu do polityki: radni sejmików województw w wyborach parlamentarnych 2015 r., „Samorząd Terytorialny” 2017, nr 1-2, s. 133-146. 
to za ich relatywną efektywność w uzyskiwaniu poparcia dla bloków, z których startowali. Ponownie widoczne były różnice dotyczące poszczególnych ugrupowań. Zdecydowanie dominowali tu reprezentanci PiS (łącznie 35 osób), następnie PO (13 osób), wreszcie PSL (6 osób). Mandat uzyskał także jedyny radny sejmiku komitetu Kukiz'15, poza parlamentem zaś znaleźli się przedstawiciele Zjednoczonej Lewicy, a także komitetów wyborczych wyborców.

Radni „zdobyli” łącznie 8,6\% głosów, które padły na listy wyborcze, z których w $2015 \mathrm{r}$. kandydowali do Sejmu. W tabeli 2 zaprezentowano „wkład” radnych w liczbę uzyskanych głosów w przypadku poszczególnych list wyborczych.

Tabela 2. Liczba głosów zdobytych przez poszczególne ugrupowania w wyborach do Sejmu RP

\begin{tabular}{|l|c|c|c|}
\hline & $\begin{array}{c}\text { Liczba głosów uzy- } \\
\text { skanych w wybo- } \\
\text { rach do Sejmu RP }\end{array}$ & $\begin{array}{c}\text { Liczba głosów } \\
\text { uzyskanych przez } \\
\text { radnych sejmików } \\
\text { kandydatów }\end{array}$ & $\begin{array}{c}\text { Odsetek głosów uzy- } \\
\text { skanych przez radnych } \\
\text { sejmików kandydatów } \\
\text { dla komitetu [\%] }\end{array}$ \\
\hline PiS & 5711687 & 471579 & 8,25 \\
\hline PO & 3661474 & 277474 & 7,57 \\
\hline PSL & 779875 & 186238 & 23,88 \\
\hline ZL & 1147102 & 73210 & 9,38 \\
\hline Kukiz'15 & 1339094 & 76675 & 2,80 \\
\hline $\begin{array}{l}\text { Komitet Wyborczy } \\
\text { Mniejszość Niemiecka }\end{array}$ & 27530 & 7728 & 0,00 \\
\hline $\begin{array}{l}\text { Komitet Wyborczy } \\
\text { Wyborców Grzegorza } \\
\text { Brauna „Szczęść Boże” }\end{array}$ & 13113 & 47 & 8,61 \\
\hline Suma & 12679875 & 1092951 & \\
\hline
\end{tabular}

* uwzględniono tylko te ugrupowania, z których radni sejmików kandydowali w wyborach do Sejmu RP.

Źródło: opracowanie własne na podstawie Wyniki wyborów do Sejmu RP oraz Wykaz komitetów wyborczych www.pkw.go.pl.

Blisko jedną czwartą głosów, które padły na listy PSL, stanowiły głosy oddane na radnych sejmików. Moglibyśmy łączyć to ze specyfiką terytorialnego poparcia dla Stronnictwa, a także z jego osobliwą siłą w samorządach. Niemniej nie możemy zapomnieć, że ów potencjał kadrowy w politycznych organizacjach zbiorowości terytorialnych obecny był dotąd raczej na poziomie lokalnym niż regionalnym ${ }^{20}$.

${ }^{20}$ K. Dojwa, Polskie Stronnictwo Ludowe na arenie samorządowej: wybrane aspekty aktywności ludowców w wyborach samorzadowych w latach 1990-2010, „Samorząd Terytorialny” 2011, nr 7-8, s. $47-60$. 
W przypadku innych ugrupowań odsetek głosów zdobytych przez radnych kandydatów był zdecydowanie niższy. Radni regionów uzyskali blisko jedną dziesiątą głosów dla Zjednoczonej Lewicy, w przypadku komitetów PiS i PO ten udział był jeszcze niższy. Podążając tym tropem, należy zauważyć, że co dwudziesty głos oddany na komitet Kukiz'15 miał samorządową proweniencję, niemniej musimy tu podkreślić start wyborczy jedynego kandydata — lidera ruchu.

\section{„Zwycięzcy"}

Przypomnijmy, że mianem zwycięzcy określono tu polityków, którzy w wyborach 2015 r. poprawili swój wynik wyborczy. Ich efektywność rzutowała także na efektywność bloku, z którym byli związani. Dlatego w tej części artykułu skoncentrowano się na porównaniu liczby głosów, które uzyskali radni, kandydując w wyborach samorządowych w 2014 r., do liczby głosów, które każdy z nich otrzymał rok później, kandydując do parlamentu.

Zanim przejdziemy do dalszych rozważań, warto $\mathrm{w}$ tym miejscu poczynić pewną uwagę metodologiczną. Do Sejmu RP w 2015 r. kandydowało 211 radnych sejmików wojewódzkich, niemniej ze względu na wycofanie się jednego z kandydatów i w związku z tym nieoddane na niego głosy uznano, że osoba ta nie będzie brana pod uwagę w dalszych analizach dotyczących uzyskanych głosów. Dlatego też w tej części artykułu liczba osób uzyskujących głosy dla swoich bloków zostaje zredukowana do 210. Natomiast do Izby Wyższej kandydowało 31 samorządowców.

Radni sejmiku, którzy później kandydowali do parlamentu i uzyskali wyższy wynik wyborczy niż w 2014 r., w wyborach samorządowych uzyskiwali poparcie od 1217 do 27275 wyborców, średnio otrzymując 8202 głosów. Rok później w wyborach parlamentarnych otrzymane przez nich poparcie mieściło się w przedziale 1522-76 675 głosów, średnio wynosząc 14263 głosów. Uśrednienie informowałoby nas o niemal podwojeniu uzyskanych głosów wyborczych, niemniej jeśli przeanalizujemy szczegółowe dane, staje się ono kontrowersyjne, gdyż z grupy 210 radnych kandydujących do Izby Niższej wynik wyższy niż w wyborach samorządowych uzyskało zaledwie 30 osób (14,3\%). Na marginesie warto dodać, że 20 osób z tej grupy uzyskało mandat wyborczy.

W przypadku blisko połowy z nich przyrost głosów wyniósł poniżej 2 tys., jednak w przypadku ośmiu osób przekroczył on aż 50 tys. (tabela 3).

Kategoria radnych sejmików kandydujących do Sejmu RP, którzy uzyskali w 2015 r. lepszy wynik wyborczy niż rok wcześniej, była stosunkowo nieliczna. Dodatkowo warto podkreślić, że grupa osób uzyskujących powyżej 5 tys. głosów była bardzo zróżnicowana. Oprócz radnych uzyskujących kilka tysięcy głosów więcej niż w wyborach samorządowych znaleźli się tu także rekordziści: lider ugrupowania Kukiz'15 oraz minister zdrowia w ówczesnym rządzie. W przypadku tych dwóch polityków różnica głosów wyniosła odpowiednio 62272 oraz 26335 głosów. 
Tabela 3. Wzrost uzyskanych głosów radnych regionów w wyborach do Sejmu RP

\begin{tabular}{|l|c|c|c|c|c|c|c|}
\hline & $\begin{array}{c}\text { Poniżej } \\
1000 \\
\text { głosów }\end{array}$ & $\begin{array}{c}1000-1999 \\
\text { głosów }\end{array}$ & $\begin{array}{c}2000-2999 \\
\text { głosów }\end{array}$ & $\begin{array}{c}3000-3999 \\
\text { głosów }\end{array}$ & $\begin{array}{c}4000-4999 \\
\text { głosów }\end{array}$ & $\begin{array}{c}\text { Powyżej } \\
5000 \\
\text { głosów }\end{array}$ & Suma \\
\hline PiS & 4 & 5 & 1 & 3 & 1 & 4 & 18 \\
\hline PO & 2 & 2 & 1 & 1 & - & 3 & 9 \\
\hline PSL & 0 & 0 & - & - & - & 0 & 0 \\
\hline ZL & 0 & 0 & 1 & - & - & 0 & 1 \\
\hline Kukiz'15 & 0 & 0 & - & - & - & 1 & 1 \\
\hline $\begin{array}{l}\text { Komitet } \\
\text { Wyborczy } \\
\text { Mniejszość } \\
\text { Niemiecka }\end{array}$ & 1 & 0 & 0 & 0 & 0 & 0 & 1 \\
\hline Suma & 7 & 7 & 3 & 4 & 1 & 8 & 30 \\
\hline
\end{tabular}

Źródło: wyliczenia własne na podstawie danych PKW.

Jeśli chodzi o ugrupowania polityczne, „Zwycięzcy” w zdecydowanej większości rekrutowali się z listy PiS (18 osób) oraz PO (9 osób). Inne komitety miały w tym gronie śladową reprezentację (Zjednoczona Lewica, rekordowy wynik Pawła Kukiza w Warszawie, wreszcie kandydat Komitetu Wyborczego Mniejszość Niemiecka na Opolszczyźnie). Wśród „wygranych” uwagę zwraca nieobecność radnych kandydatów Polskiego Stronnictwa Ludowego - w przypadku tej partii żaden z radnych sejmików w 2015 r. nie uzyskał lepszego wyniku niż w 2014. Tacy radni byli na listach innych podmiotów, personalnie ponownie uzyskali akceptację wyborczą zbiorowości, ich poparcie zaś „pracowało” na całość wyniku wyborczego.

Natomiast jeśli chodzi o Senat RP, sytuacja była odmienna niż w przypadku Sejmu, gdzie stosunkowo nieliczni radni uzyskali lepszy rezultat wyborczy niż dotychczas. Do Izby Wyższej kandydowało 31 radnych sejmików, 10 osób uzyskało mandat. Każdy z radnych kandydatów otrzymał liczbę głosów wyższą niż w 2014 r., co moglibyśmy tłumaczyć charakterystyką samych wyborów do tego gremium oraz racjonalnością polityczną kandydatów i podmiotów instytucjonalnych. Przy porównywaniu „zysków” głosów uzyskanych przez radnych kandydujących do sejmu i senatu na pierwszym miejscu plasuje się ich liczba oraz dominacja kandydatów prawicy. 
Katarzyna Dojwa-Turczyńska

Tabela 4. Wzrost uzyskanych głosów radnych regionów w wyborach do Senatu RP

\begin{tabular}{|l|c|c|c|c|c|c|c|}
\hline & $\begin{array}{c}\text { Poniżej } \\
10000 \\
\text { głosów }\end{array}$ & $\begin{array}{c}10000- \\
19999 \\
\text { głosów }\end{array}$ & $\begin{array}{c}20000- \\
29999 \\
\text { głosów }\end{array}$ & $\begin{array}{c}30000- \\
39999 \\
\text { głosów }\end{array}$ & $\begin{array}{c}40000- \\
49999 \\
\text { głosów }\end{array}$ & $\begin{array}{c}\text { Powyżej } \\
50000 \\
\text { głosów }\end{array}$ & Suma \\
\hline PiS & 0 & 0 & 0 & 3 & 1 & 7 & 11 \\
\hline PO & 0 & 0 & 2 & 1 & 0 & 2 & 5 \\
\hline PSL & 6 & 5 & 1 & 0 & 0 & 0 & 12 \\
\hline ZL & 0 & 0 & 0 & 0 & 0 & 0 & 0 \\
\hline Kukiz'15 & 0 & 0 & 0 & 0 & 0 & 0 & 0 \\
\hline Inne & 1 & 2 & 0 & 0 & 0 & 0 & 3 \\
\hline Suma & 7 & 7 & 3 & 4 & 1 & 9 & 31 \\
\hline
\end{tabular}

^Komitet Wyborczy Mniejszość Niemiecka, Komitet Wyborczy Wyborców Kandydata na Senatora Jana Bobek, Komitet Wyborczy Wyborców Razem z Lidią Błądek.

Źródło: wyliczenia własne na podstawie danych PKW.

O ile zatem wśród radnych ubiegających się o mandat w Senacie RP dominowali radni PSL oraz PiS (odpowiednio 12 oraz 11 kandydatów), o tyle co do kandydatów Stronnictwa przyrosty głosów były zauważalnie niższe niż w przypadku Prawa i Sprawiedliwości.

Podsumowując, kategoria radnych, którzy kandydując w wyborach parlamentarnych, uzyskują więcej głosów wyborczych niż rok wcześniej, jest stosunkowo nieliczna. Dominują wśród nich reprezentanci Prawa i Sprawiedliwości (29 osób), a w dalszej kolejności Platformy Obywatelskiej (14 osób). Stosunkowo dobrze w tym zestawieniu prezentują się radni Polskiego Stronnictwa Ludowego (12 osób), niemniej zwraca uwagę ich nieobecność wśród kandydatów do Izby Niższej.

\section{„Przegrani”}

„Przegrani”, czyli radni, którzy w ciągu roku stracili część poparcia wyborczego, zauważalnie dominowali w gronie samorządowców aspirujących do polityki na szczeblu ogólnopolskim. W sytuacji gdy o wejście do Sejmu RP walczyło 210 radnych sejmików, aż 180 osób (85,7\%) uzyskało w wyborach parlamentarnych mniej głosów niż rok wcześniej w wyborach samorządowych.

Jeśli chodzi o poparcie wyborcze dla radnych kandydujących następnie do Sejmu RP, to w 2014 r. zamykało się ono w przedziale 1 093-30 856 głosów. Radni „przegrani” zdobyli łącznie 1712046 głosów (średnia: 9511). Zwraca uwagę wyższe uśrednione poparcie dla tych samorządowców niż w przypadku „wygranych” (przypomnijmy, wynosiło ono 8202 głosy). 
„Wygrani" $\mathrm{i}$ "przegrani”. Analiza zmian poparcia

\begin{tabular}{|c|c|c|c|c|c|c|c|c|}
\hline 氶 & $\underset{F}{*}$ & बे & $\infty$ & $\stackrel{-}{-}$ & 0 & $\neg$ & $\neg$ & $\stackrel{\infty}{-}$ \\
\hline 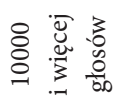 & $\exists$ & 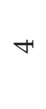 & $\simeq$ & $\neg$ & 0 & 0 & $\neg$ & Әे \\
\hline 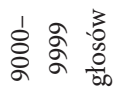 & - & $m$ & $\wedge$ & - & 0 & 0 & 0 & $\simeq$ \\
\hline 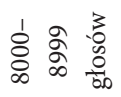 & N & - & in & 0 & 0 & 0 & 0 & $\infty$ \\
\hline 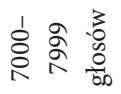 & N & $\sim$ & $a$ & 0 & 0 & 0 & 0 & $\stackrel{m}{\sim}$ \\
\hline $\begin{array}{l}1 \\
8 \\
8 \\
0 \\
0\end{array}$ & N & $m$ & $a$ & 0 & 0 & 0 & 0 & 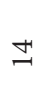 \\
\hline 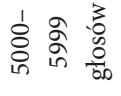 & $m$ & $\psi$ & $\forall$ & - & 0 & 0 & 0 & 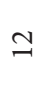 \\
\hline 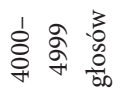 & $\wedge$ & $n$ & $\infty$ & 0 & 0 & 0 & 0 & $\stackrel{\infty}{\sim}$ \\
\hline 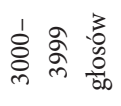 & in & - & $\wedge$ & $\sim$ & 0 & 0 & 0 & $\stackrel{20}{\longrightarrow}$ \\
\hline 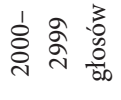 & in & $\infty$ & $\infty$ & - & 0 & 0 & 0 & $\widetilde{\sim}$ \\
\hline 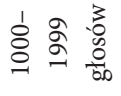 & $\psi$ & in & $\stackrel{\sim}{\sim}$ & $m$ & 0 & $\neg$ & 0 & $\stackrel{\mathscr{2}}{\sim}$ \\
\hline 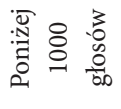 & $\mathrm{N}$ & in & 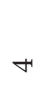 & - & 0 & 0 & 0 & $\underset{\sim}{\sim}$ \\
\hline & $\ddot{z}$ & 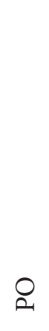 & $\vec{\sim}$ & $\vec{N}$ & 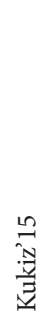 & 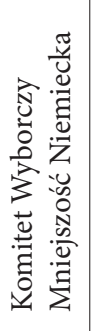 & 怘 & $\underset{\Xi}{\Xi}$ \\
\hline
\end{tabular}


W 2015 r. głosy zdobyte przez „przegranych” samorządowców zamykały się w przedziale od 47 do 27568 (łącznie 672702 głosów, czyli średnio 3737). Z tej licznej kategorii radnych mandaty poselskie otrzymało 25 osób. Różnica, a raczej spadek liczby głosów między 2014 a 2015 r. w przypadku poszczególnych osób oscylował między jednym a 22872 głosów.

Relatywnie najniższy spadek poparcia, wynoszący do 4999 głosów, miał miejsce w przypadku połowy radnych kandydatów PiS ( 23 osoby) oraz blisko połowy reprezentantów i aspirantów z PO (22 osoby). Jeśli chodzi o Ludowców, udział był porównywalny (39 osób).

Średni spadek poparcia (5000-9999 głosów) odnotowano u jednej czwartej reprezentantów PiS (10 osób), jednej trzeciej kandydatów z listy PO (13 osób), a także blisko jednej trzeciej kandydatów PSL (34 osoby).

Natomiast najwyższy spadek poparcia, wynoszący 10000 głosów i więcej, odnotowywano w przypadku jednej czwartej radnych kandydatów PiS (11 osób), niespełna jednej dziesiątej aktywistów PO (4 osoby), a także jednej siódmej (12) Ludowców.

Wśród ogółu kandydujących w wyborach parlamentarnych (a szczególnie w wyborach do Sejmu RP) zastanawiająca jest dominacja radnych, którzy w ciągu roku stracili część uzyskanego wcześniej poparcia. Mogły na to wpłynąć różne czynniki: zarówno wspomniane postacie rozpoznawalnych liderów obecnych na listach parlamentarnych, miejsce na liście wyborczej czy środki materialne będące $\mathrm{w}$ dyspozycji kandydatów, jak i względnie mała atrakcyjność wyborcza statusu radnego samorządu wojewódzkiego. Te przesłanki mogły tkwić także w ograniczonej aktywności samych radnych kandydatów, gdzie decyzja o kandydowaniu była postrzegana raczej jako element lojalności politycznej względem bloku niż faktyczna chęć partycypacji w polityce ogólnopolskiej. Ograniczenia materiału wtórnego pozwalają jedynie sformułować te hipotezy, ich rozstrzygnięcie wymagałoby sięgnięcia po badania empiryczne.

\section{Partyjne zyski i straty. Casus Polskiego Stronnictwa Ludowego}

Jak już wskazano we wstępie, wybory parlamentarne 2015 r. dokonały gruntownej rekonstrukcji sceny politycznej - po raz pierwszy bezwzględną większość uzyskało jedno ugrupowanie, na scenie polityki ogólnopolskiej pojawiły się dwa podmioty, które powstały w tymże roku, postkomunistyczna lewica utraciła swoją reprezentację. Kwestie kluczowe dla polskiej sceny politycznej w istotny sposób wpłynęly także na prezentowane w artykule badania. Dlatego w tym miejscu skoncentrowano się na samorządowcach regionów kandydujących do parlamentu jedynie z list trzech ugrupowań politycznych. Stąd ograniczenie analiz tej części artykułu jedynie do PiS, PO oraz PSL, czyli partii, które nie tylko zgłosiły listy i zdobyły mandaty w wyborach do rad regionów, ale dodatkowo znalazły się w parlamencie. 
Zwycięzcą wyborów parlamentarnych stał się komitet PiS. W wyborach do Sejmu RP z jego list kandydowało 62 radnych sejmików, z czego mandaty uzyskało 28 osób. W tej liczbie znalazło się 18 osób, które w 2015 r. uzyskały lepszy wynik wyborczy niż w roku 2014. W wyborach samorządowych późniejsi radni kandydaci uzyskali łącznie 691977 głosów, w roku 2015 zaś poparło ich 471579 wyborców, co oznacza, że radni regionów in gremio utracili 220398 głosów (31,9\%). Jako kandydaci w wyborach do Izby Niższej uzyskiwali bardzo zróżnicowane poparcie, mieszczące się w przedziale od 628 do 27568 głosów. Rok wcześniej uzyskane przez nich poparcie wynosiło od 2489 do 30856 głosów. Rekordzista w ciągu roku zwiększył swoje poparcie o 7654 głosów, radny kandydat konstruujący wartość skrajną przeciwległego bieguna stracił natomiast 17029 głosów.

Jeśli chodzi o PO, to z jej list kandydowało w 2015 r. do Izby Niższej 47 radnych sejmików, wszyscy kandydaci ponownie startowali w obrębie swojego regionu, przy czym jedna osoba w roku 2014 była kandydatem, a potem radnym innego ugrupowania. Mandaty w Izbie Niższej otrzymało dziewięć osób. Także dziewięciu radnych uzyskało w roku 2015 lepszy wynik wyborczy niż w wyborach samorządowych. Radni kandydaci PO uzyskali w 2014 r. poparcie personalne mieszczące się w przedziale od 1217 do 27275 (łącznie poparcie 394714 osób). Natomiast rok później liczba zdobytych przez nich głosów oscylowała w przedziale od 412 do 53610 głosów (poparcie łączne: 277 474). W porównaniu z Prawem i Sprawiedliwością zwraca uwagę rozpiętość liczby głosów uzyskanych przez kandydatów $\mathrm{w}$ wyborach parlamentarnych. Tu również mamy do czynienia z niższą liczbą głosów zdobytych przez radnych kandydatów w 2015 r. niż w wyborach samorządowych (117 240, tj. 29,7\%).

Z list PSL wystartowało do Izby Niższej 85 radnych sejmików, jednak mandat uzyskało jedynie sześć osób. Żadna z nich nie polepszyła swojego wyniku wyborczego w stosunku do wyborów 2014 r., wszyscy natomiast kandydowali w obrębie swoich województw, a także zachowali ciągłość listy wyborczej. W roku 2014 poparcie dla Ludowców zamykało się w przedziale od 1093 do 23324 głosów (uzyskując łączne poparcie 698886 wyborców). Rok później sytuacja była odmienna. Poparcie dla radnych kandydatów wynosiło wtedy od 241 do 7010 głosów. Dolny próg konstruuje zatem wartość głosów nieporównywalnie niższą od analogicznej wartości w przypadku PiS (w wyborach parlamentarnych najniższa liczba głosów, która padła na kandydata prawicy, przekraczała 600 głosów), ale także PO (ponad 400 głosów). Maksymalna liczba głosów zdobytych przez kandydata Stronnictwa nieznacznie przekroczyła zaledwie 7 tys., gdy tymczasem w przypadku PiS było to ponad 27 tys., w przypadku PO zaś ponad 53 tys. Łącznie w 2015 r. na radnych Ludowców oddano zaledwie 186238 głosów, co oznacza, że radni kandydaci do Sejmu RP tracą 512648 głosów (73,4\%).

Spadek poparcia wyborczego dla radnych kandydatów Ludowców był zauważalny w skali całego kraju, niemniej w niektórych regionach był on zauważalnie wyższy. 
Tabela 6. Liczba głosów oddanych na PSL w roku 2014 i 2015 w poszczególnych regionach

\begin{tabular}{|c|c|c|c|c|c|}
\hline \multirow[b]{2}{*}{ Lp. } & \multirow[b]{2}{*}{ Województwo } & \multirow{2}{*}{$\begin{array}{c}\text { Liczba } \\
\text { kandydujących } \\
\text { radnych } \\
\text { sejmików z PSL }\end{array}$} & \multicolumn{2}{|c|}{$\begin{array}{l}\text { Liczba } \\
\text { uzyskanych } \\
\text { głosów }\end{array}$} & \multirow[b]{2}{*}{$\begin{array}{c}\text { Różnica/ } \\
\text { wielokrotność } \\
\text { spadku (spadek } \\
\text { liczby głosów } \\
\text { w roku } 2015 \\
\text { w stosunku } \\
\text { do 2014) }\end{array}$} \\
\hline & & & 2014 & 2015 & \\
\hline 1. & dolnośląskie & 3 & 26059 & 8903 & $17156 / 2,9$ \\
\hline 2. & kujawsko-pomorskie & 5 & 34360 & 5565 & $28795 / 6,1$ \\
\hline 3. & lubelskie & 5 & 53360 & 12984 & $40376 / 4,1$ \\
\hline 4. & lubuskie & 5 & 16576 & 4594 & $11982 / 3,6$ \\
\hline 5. & łódzkie & 7 & 90278 & 22124 & $68154 / 4,0$ \\
\hline 6. & małopolskie & 5 & 52202 & 10113 & $42089 / 5,1$ \\
\hline 7. & mazowieckie & 7 & 76899 & 14844 & $62055 / 5,1$ \\
\hline 8. & opolskie & 6 & 25237 & 8155 & $17082 / 3,0$ \\
\hline 9. & podkarpackie & 4 & 53765 & 13372 & $40393 / 4,0$ \\
\hline 10. & podlaskie & 6 & 48166 & 17297 & $30869 / 2,7$ \\
\hline 11. & pomorskie & 7 & 51238 & 13038 & $38200 / 3,9$ \\
\hline 12. & śląskie & 5 & 36653 & 10204 & $26449 / 3,5$ \\
\hline 13. & świętokrzyskie & 4 & 39310 & 15468 & $23842 / 2,4$ \\
\hline 14. & warmińsko-mazurskie & 8 & 48891 & 12659 & $36232 / 3,8$ \\
\hline 15. & wielkopolskie & 3 & 23624 & 9011 & $14613 / 2,6$ \\
\hline 16. & zachodniopomorskie & 5 & 22268 & 7907 & $14361 / 2,8$ \\
\hline
\end{tabular}

Źródło: wyliczenia własne na podstawie danych PKW.

W tabeli 7 zaprezentowano liczby głosów radnych sejmików z ramienia PSL w poszczególnych regionach, którzy zdecydowali się walczyć o mandat parlamentarny. Liczby bezwzględne zamykają się w przedziale 11982 i 68154 głosów. Biorąc jednak pod uwagę skalę spadku poparcia dla Ludowców, lepszą egzemplifikacją wydaje się sięgnięcie po wielokrotność spadku. Jest ona stosunkowo mała w przypadku województwa świętokrzyskiego: PSL uzyskuje tu tylko 2,4 razy mniej głosów niż przed rokiem. Podobnie będzie także w Wielkopolsce (2,6 mniej) i Podlasiu (odpo- 
wiednio 2,7), w Zachodniopomorskiem (spadek 2,8-krotny) i Dolnośląskiem (2,9). Natomiast ponad pięciokrotnie spadnie poparcie na Mazowszu oraz w Małopolsce (o 5,1), rekord zaś ustanowi województwo kujawsko-pomorskie - tu poparcie dla Ludowców, dodajmy, że tych samych osób co rok wcześniej, spadnie sześciokrotnie.

Oczywiście spadek liczby uzyskanych rok po roku głosów przez radnych kandydatów jest widoczny w przypadku trzech partii. Niemniej zastanawia jego skala w przypadku PSL. Trudno wskazać kryzysy wizerunkowe Stronnictwa, które miałyby tak zauważalny wpływ na poparcie, które uzyskali jego mandatariusze samorządu. Tłumaczenie go kosztami partycypacji w koalicji rządzącej przez osiem lat jest również bezzasadne, gdyż w przypadku koalicjanta Ludowców, czyli Platformy Obywatelskiej, nie ma aż takiej różnicy. Analogicznie byłoby w przypadku kreacji władz regionów - oba ugrupowania partycypowały tu we władzy, skąd więc spadek poparcia dla jednego z nich? Wyjaśnieniem mogłyby być nieatrakcyjne pozycje radnych kandydatów na poselskich listach wyborczych, lecz ta interpretacja również jest bezzasadna. Kandydaci na listach poselskich PO i PiS zajmowali średnio pozycje ósme, gdy tymczasem w przypadku kandydatów PSL były to pozycje szóste. Jeszcze atrakcyjniej prezentowałyby się miejsca zajmowane przez radnych kandydatów Ludowców w porównaniu z innymi partiami, gdyby ostatnim na liście pozycjom umownie przyznać liczbę punktową pozycji trzecich, ze względu na ich atrakcyjność dla kandydatów. Wtedy, ponownie uśredniając, radni sejmików z ramienia PSL statystycznie zajęliby piątą pozycję. Identyczny zabieg zastosowany $\mathrm{w}$ przypadku PiS sytuowałby ich radnych na pozycji siódmej, a w przypadku PO niemal ósmej (średnia to 7,6). Kluczem nie są także pozycje na listach zajmowanych w wyborach samorządowych, co zaprezentowano w tabeli 7.

Tabela 7. Pozycje radnych-kandydatów na listach w wyborach do sejmików w 2014 roku

\begin{tabular}{|l|c|c|c|c|c|}
\hline & Pozycja 1 & Pozycja 2 & Pozycja 3 & $\begin{array}{c}\text { Pozycja 4- } \\
\text { przedostatnia }\end{array}$ & $\begin{array}{c}\text { Pozycja } \\
\text { ostatnia }\end{array}$ \\
\hline PiS & 38 & 9 & 7 & 9 & 1 \\
\hline PO & 16 & 10 & 8 & 12 & 1 \\
\hline PSL & 36 & 21 & 11 & 10 & 7 \\
\hline Suma & 90 & 40 & 26 & 31 & 9 \\
\hline
\end{tabular}

Źródło: wyliczenia własne na podstawie danych PKW.

O ile zatem w 2014 r. mogliśmy zastanawiać się nad fenomenem bardzo wysokiego poparcia dla Polskiego Stronnictwa Ludowego w wyborach samorządowych, o tyle trudno wytłumaczyć przytłaczającą klęskę osób, które poddały się wyborczej weryfikacji rok później. 
Podsumowując, kandydaci każdej z trzech partii, poddając się weryfikacji wyborczej, uzyskują niższe poparcie wyborców niż rok wcześniej, w przypadku PO i PiS te straty oscylują poniżej jednej trzeciej, w przypadku PSL - trzech czwartych. Można jednak uzasadnić to tym, że radni każdego bloku zajmują w wyborach do Sejmu RP gremialnie mniej atrakcyjne miejsca na listach niż w wyborach samorządowych, wiele posiadanych przez nich wcześniej pozycji pierwszych, drugich lub trzecich przypada innym kandydatom ${ }^{21}$. Poszczególne partie umieszczają na swych listach zróżnicowane liczby samorządowców regionów, poparcie dla nich także się różni. Stosunkowo najmniej „efektywni” dla partii stają się w wyborach parlamentarnych samorządowcy PO, których wkład w pulę uzyskanych przez partię głosów nie osiąga nawet procenta (jest to $0,75 \%)$. Zdecydowanie więcej głosów przynoszą swojemu ugrupowaniu radni sejmików z PSL - ich wkład w liczbę uzyskanych głosów przekracza $2 \%$ $(2,38 \%)$. W przypadku PiS ten wynik jest jednak nieporównywalnie większy radnym wojewódzkim Prawica zawdzięcza osiem na sto głosów $(8,26 \%)$. Te odsetki nie wydają się duże, ale nabierają większego znaczenia, jeśli uświadomimy sobie, jak skromna de facto była liczba radnych w gronie wszystkich kandydatów poszczególnych bloków. Przypomnijmy, że każda partia zgłosiła na listach do Izby Niższej ponad 900 kandydatów (PiS i PSL po 920, natomiast PO - 919 osób) ${ }^{22}$.

\section{Zakończenie}

Celem artykułu była próba udzielenia odpowiedzi na pytania o poziom aspiracji parlamentarnych radnych sejmików oraz zastanowienie się nad tym, czy regionalni samorządowcy zwiększyli, czy też zmniejszyli swoje poparcie wśród elektoratu. W centrum zainteresowań znalazło się także uchwycenie różnic i podobieństw między aktorami politycznymi w tym zakresie. Analiza statystyk urzędowych pokazuje, że na start wyborczy zdecydowało się dwóch na pięciu samorządowców. To stosunkowo mało, jeśli potraktujemy samorząd regionu jako pewien etap kariery politycznej, ale i stosunkowo dużo, jeśli weźmiemy pod uwagę często przeciwstawiane polityce „centralnej” aksjologiczne i normatywne funkcje, role, zadania czy pochodzenie samorządów jako takich. Radni zainteresowani zmianą mandatu w samorządzie na mandat w Izbie Niższej generalnie częściej tracili niż zyskiwali poparcie, co moglibyśmy tłumaczyć stosunkowo nikłym związaniem samorządu regionu ze zbiorowością, obecnością na listach stronnictw liderów i osób o wyższym poziomie identyfikacji, wreszcie stosunkowo mało atrakcyjnymi, „niebiorącymi” miejscami na listach. Pewien wyjątek stanowili ci aspirujący do Izby Wyższej - wprawdzie tacy

21 https://parlament2015.pkw.gov.pl/349_Wyniki_Sejm (dostęp: 15 marca 2016).

22 Obliczenia własne na podstawie list kandydatów w wyborach do Sejmu RP, https://parlament2015.pkw.gov.pl/344_sejm (dostęp: 10 lipca 2016). 
radni kandydaci byli stosunkowo nieliczni, niemniej uzyskali oni wyższe poparcie wyborców niż rok wcześniej. Skoro o miejscach na listach mowa, w roku 2014 radni wojewódzcy dysponowali atrakcyjnymi lokalizacjami, rok później statystycznie były one już zdecydowanie gorsze w przypadku Platformy Obywatelskiej oraz Prawa i Sprawiedliwości. Stosunkowo najatrakcyjniejsze były w przypadku PSL, jednak nie zniwelowało to bardzo wysokiej utraty zainteresowania wyborców tą partią.

Uzasadnienia przewagi „przegranych” nad „zwycięzcami” dostarcza nam także literatura przedmiotu, gdzie wiele pisze się o dystansie między mieszkańcami a wyższymi poziomami samorządu terytorialnego ${ }^{23}$. Równocześnie mieszkańcy w małym stopniu angażują się w działania na rzecz powiatu i regionu, rzadko interesują się tym, co się dzieje na tych szczeblach samorządu ${ }^{24}$. Owo oderwanie powiatu, a szczególnie regionu od mieszkańców z perspektywy podmiotów sprzyja upartyjnieniu samorządów wojewódzkich, jest katalizatorem traktowania przez część regionalnych samorządowców mandatów regionalnych jako „biletów wejścia” do polityki szczebla krajowego. Wprawdzie wiele się pisze o procesualnym, niestatycznym ${ }^{25}$ postrzeganiu samorządu i samorządności, niemniej w tym zakresie mamy do czynienia raczej ze stagnacją ${ }^{26}$ i trudno upatrywać w przyszłości zmian w tym zakresie.

\section{Bibliografia}

Antoszewski A., Wszystko przez ten system... (wyborczy), [w:] Gra o regiony. Wybory do sejmików województw w 2010 roku, red. R. Alberski, M. Cichosz, K. Kobielska, Wrocław 2013.

Bober J. et al., Narastające dysfunkcje, zasadnicze dylematy, konieczne działania. Raport o stanie samorząności terytorialnej w Polsce, Kraków 2013.

Dojwa K., Polskie Stronnictwo Ludowe na arenie samorzadowej: wybrane aspekty aktywności ludowców w wyborach samorządowych w latach 1990-2010, „Samorząd Terytorialny” 2011, nr 7-8.

Dojwa K., Samorzad terytorialny $i$ władze samorzadowe w percepcji społecznej. Wybrane aspekty socjologiczne, [w:] Polityka na szczeblu samorządu terytorialnego, red. S. Sulowski,„Studia Politologiczne" 20, Warszawa 2011.

Dojwa K., Sejmiki jako regionalne sceny polityczne: trwałość aspiracji samorządowych oraz preferencji partyjnych radnych sejmików wojewódzkich, „Samorząd Terytorialny” 2007, nr 10.

Dojwa-Turczyńska K., Z samorzadu do polityki: radni sejmików województw w wyborach parlamentarnych 2015 r., „Samorząd terytorialny” 2017, nr 1-2.

Gąciaż B., Bartkowski J., Samorząd a rozwój. Instytucje, obywatele, podmiotowość, Warszawa 2012.

Hryniewicz J.T., Analiza funkcjonowania samorzadu lokalnego w oparciu o kluczowe kategorie nauk o zarządzaniu: misje, cele, własność, kontekst organizacyjny i efektywność, [w:] 20 lat samorządu terytorialnego w Polsce. Sukcesy, porażki, perspektywy, red. K. Mieczkowska-Czerniak, K. Radzik-Maruszak, Lublin 2012.

${ }^{23}$ B. Gąciaż, J. Bartkowski, op. cit., s. 191.

24 Ibidem, s. 192.

25 Por. m.in. R. Kamiński, Odbudowa samorządu terytorialnego jako próba decentralizacji administracji władzy publicznej, „E-Politikon” 2015, nr 15. Dyskusje o samorządzie terytorialnym, s. 91-112.

26 Por. K. Dojwa, Sejmiki jako regionalne sceny polityczne: trwałość aspiracji samorządowych oraz preferencji partyjnych radnych sejmików wojewódzkich, „Samorząd Terytorialny” 2007, nr 10, s. 7-21. 
Jaskiernia J., Konstytucyjny model samorządu terytorialnego - czy przetrwat próbę czasu?, [w:] $X X$ lat samorządu terytorialnego w Polsce. Doświadczenia-problemy-perspektywy, red. J. Kowalik, A. Bednarz, Torun 2011.

Kamiński R., Odbudowa samorządu terytorialnego jako próba decentralizacji administracji władzy publicznej, „E-Politikon” 2015, nr 15. Dyskusje o samorządzie terytorialnym.

Kocot G., Wybory samorzadowe 2014 w Polsce. Przepisy wyborcze, frekwencja i wyniki, „Zeszyty Naukowe Towarzystwa Doktorantów UJ. Nauki społeczne" 2015, nr 11.

Pokładecki J., Aktywność w wyborach do organów samorządu terytorialnego jako przejaw partycypacji politycznej, [w:] Partycypacja społeczna w samorzadzie terytorialnym, red. B. Dolnicki, Warszawa 2014.

Sulowski S., Wprowadzenie, [w:] Polityka na szczeblu samorzadu terytorialnego, red. S. Sulowski, „Studia Politologiczne” 20, Warszawa 2011.

Szczudlińska-Kanoś A., Regionalne elity polityczne w Polsce, Kraków 2013.

\section{Źródła internetowe}

http://parlament2015.pkw.gov.pl/349_Wyniki_Sejm.

http://parlament2015.pkw.gov.pl/351_Wyniki_Senat.

https://parlament2015.pkw.gov.pl/344_sejm.

Podział mandatów w sejmikach województw według komitetów wyborczych, http://pkw.gov.pl/g2/oryginal/2014_11/8b4fcc8febb13dc7d88f8e386e3ab5a4.pdf.

http://prezydent2015.pkw.gov.pl/319_Pierwsze_glosowanie.

http://samorzad2014.pkw.gov.pl/357_rady_woj.

\section{Obwieszczenia PKW}

Obwieszczenie Państwowej Komisji Wyborczej z dnia 23 listopada 2014 r. o zbiorczych wynikach wyborów do rad na obszarze kraju, przeprowadzonych w dniu 16 listopada 2014 r., (Dz.U. z 2014 r. poz. 1640), http://pkw.gov.pl/obwieszczenia-i-komunikaty-samorzad-2014/obwieszczenie-panstwowej-komisji-wyborczej-z-dnia-23-listopada-2014-r-o-zbiorczych-wynikach-wyborow-do-rad-na-obszarze-kraju-przeprowadzonych-w-dniu-16-listopada-2014-r.html.

Obwieszczenie Państwowej Komisji Wyborczej z dnia 27 października 2015 r. o wynikach wyborów do Sejmu Rzeczypospolitej Polskiej przeprowadzonych w dniu 25 października 2015 r. (Dz.U. z 2015 r. poz. 1731).

Obwieszczenie Państwowej Komisji Wyborczej z dnia 27 października 2015 r. o wynikach wyborów do Senatu Rzeczypospolitej Polskiej przeprowadzonych $w$ dniu 25 października 2015 r. (Dz.U. z 2015 r. poz. 1732). 